\title{
UNA FORMA ALTERNATIVA DE LA PIEDAD POPULAR: LAS COFRADÍAS DE VÍA SACRA EN GRANADA ${ }^{1}$
}

\author{
Miguel Luis LóPez-GuAdAlupe MuÑoz \\ Universidad de Granada
}

Fecha de recepción: diciembre 2010

Fecha de aceptación: abril 2013

El siglo XVI supuso una época decisiva para el avance de la piedad pasionista en toda España; la floración de cofradías penitenciales es buena muestra de ello. El proceso, por supuesto, continuó en la centuria siguiente, encontrando la piedad popular pasionista un aliado en el avance imparable del Barroco. Fue entonces cuando las estaciones de penitencia derrocharon arte y boato, con el concurso de la imaginería procesional, pero también de las artes aplicadas, del canto, de la música y de las escenificaciones teatrales. Toda una teatralidad barroca rodeó entonces las procesiones que manifestaban al pueblo fiel la pasión y muerte de Cristo. Han quedado vestigios de este proceso, aunque no el clima de conmoción que recreaban en el espacio abierto de la calle, cuya finalidad última era la contrición de los pecados y la conversión de las almas.

Justamente entonces la piedad pasionista busca nuevas fórmulas, más en el terreno de lo individual-devocional que en el de lo colectivo-popular. No es ajeno a ello la aparición de fórmulas comunitarias muy elaboradas y espirituales, y aun elitistas, como la Escuela de Cristo, las congregaciones o el amplio mundo de las órdenes terceras. Lo más llamativo es que estas propuestas tendieron a universalizarse. Tenían sin duda un gran atractivo: para los fieles significaban protagonismo y distinción; para la jerarquía, fórmulas de encuadramiento de los fieles y, por ende, de control. El campo natural en el que confluyeron estas nuevas hermandades o congregaciones fue el de parroquia y algunos prelados se jactaban de ello, como hacía el de Granada, D. Martín

\footnotetext{
1. Este trabajo se inscribe en el proyecto de investigación «El hecho cotidiano en la Monarquía Española de la Edad Moderna: lo doméstico entre lo privado y lo público. Historia comparada entre el interior y la periferia. 3. Granada» del Ministerio de Ciencia y Tecnología (HAR2011-26435-C03-03).
} 
de Ascargorta, en su relación ad limina de 1699, al consignar su empeño por impulsar cofradías dedicadas a los «misterios de nuestra redención», que organizaban procesiones y penitencias públicas en los días de Cuaresma y Semana Santa ${ }^{2}$. Queda claro en esta expresión que, debidamente ubicadas en el marco parroquial, estaban llamadas a ser contrapeso a las arraigadas y siempre rijosas -en su relación con la jerarquía eclesiástica- cofradías de penitencia.

Podemos identificar esas cofradías, eminentemente parroquiales, erigidas en torno a los misterios de la Pasión del Señor como congregaciones de vía sacra, pero sin olvidar que el germen fecundo que las alumbró fue la religiosidad derivada de las órdenes religiosas. Por eso, en el caso de Granada, el paradigma de hermandad de vía sacra es la Orden Tercera de S. Francisco; a partir de ella vendrá su extensión. ¿Se trata de una reacción desde el ámbito parroquial a las arraigadas devociones estimuladas por los frailes?

Tales asociaciones, rebasando el marco de la Semana Santa, van extendiendo el culto a Cristo en la Pasión a lo largo de todo el año. Las más numerosas, en torno al Crucificado, se concretan en cultos devotos, y a veces solemnes, durante el mes de mayo (en torno a la festividad de la Invención de la Sta. Cruz) y, en menor medida, en el de septiembre (Exaltación de la Sta. Cruz), pero no son los únicos momentos del año, pues en realidad fue la Cuaresma el tiempo más propicio para esa otra manifestación, más fervorosa pero impactante, que constituía el rezo callejero del vía crucis.

\section{CONFORMACIÓN DE UN MODELO CONFRATERNAL SUI GENERIS}

\subsection{Origen de la vía sacra}

Ciertamente, lo característico de las hermandades de vía sacra es el rezo del vía crucis, pero no en el interior de los templos, sino al aire libre, a través de trazados urbanos y sobre todo campestres, concluyendo en pintorescos parajes, elevados, a las afueras de la ciudad. La topografía urbana de Granada se prestaba a la proliferación de estos recorridos, que de trecho en trecho eran jalonados por cruces e incluso oratorios que recordaban las catorce -inicialmente doce- estaciones de la «vía sacra» recorrida por Jesucristo en Jerusalén, desde su condena a muerte hasta el depósito de su cadáver en el sepulcro. Precisamente con frecuencia estas sendas dolorosas acababan en una ermita con título del Sto. Sepulcro y/o sobre un montículo denominado significativamente de la «Resurrección».

Según la tradición medieval, el ejercicio del vía crucis, vía sacra o via calvariae tuvo su origen en la misma Virgen María, «bolviendo (después de aver dexado a su amantísimo Hijo en el sagrado Sepulcro), traspasada de dolor, por los mismos pasos que aquel inocentísimo Cordero dio con la pesada Cruz a cuestas en beneficio del linage humano, y por redimir al hombre, hasta el Monte Calvario, donde entregó volunta-

2. Archivio Segreto Vaticano, S. Congr. Concilii, Relationes 370B, visita ad limina de 1699. 
riamente vida y alma a su Eterno Padre por nuestro remedio» ${ }^{3}$. La eficacia espiritual de este ejercicio estaba muy extendida y consistía en la creencia de que «qualquiera, por muchos y graves pecados que aya cometido, podrá tener esperança de perdón dellos» ofreciendo al Señor la imitación de su Pasión. Reflexiones de este tipo fueron moneda corriente en las visiones, meditaciones o escritos de personajes como Sta. Brígida, Stas. Paula y Eustaquia, S. Ildefonso, Sta. Gertrudis, Sta. Catalina, S. Alberto Magno, el padre Cristóbal de Castro, Enrique Suson...

Como puede observarse, se trata de una práctica expiatoria emparentada con la disciplina pública que practicaban originariamente las cofradías de penitencia y sangre. Pero con un trasunto más elaborado, transido de meditación y de elección personal, más místico, en suma, al entroncar con abundantes milagros y apariciones, hechos insólitos que constituían un buen medio para instruir al pueblo, proponiendo siempre edificantes ejemplos a imitar. En una de esas apariciones, dijo Cristo a un religioso: «No me puedes hazer servicio mas agradable... que ayudarme a llevar esta pesada Cruz», añadiendo la forma de llevarla: «en el coraçón, con la continua memoria, compasión y meditación della; en la boca, dándome gracias con devoción y afecto de que en ella te redimí; en los oydos, oyendo con sabroso gusto y regaladísimo sentimiento quántas fueron mis penas; en las espaldas, macerando y mortificando tu carne» ${ }^{4}$.

La elocuente descripción del clérigo Van der Hammen no es sólo una argumentación doctrinal, sino sin duda una reflexión que se repetía hasta la saciedad a los hermanos granadinos de la Tercera Orden de S. Francisco, aquélllos que frecuentaban la vía sacra del cerro de Valparaíso, llamativo nombre del paraje conocido también como Sacromonte. El origen de este ejercicio lo remonta Van der Hammen a los reyes de Sicilia, Roberto y Sancha, que entregaron en el siglo XIV los Santos Lugares, «donde oy ay cinco Conventos y muchas Iglesias y Hermitas», a los religiosos franciscanos. La práctica de este rezo se extendió con gran rapidez. En España, de la mano de la orden franciscana, tuvo gran aceptación y pronto empezó a recrearse el camino hacia el Calvario en lugares agrestes, algunos tan conocidos como Escalaceli en Córdoba (por obra de fray Álvaro de Córdoba en el siglo XV) $)^{5}$ o la Cruz del Campo en Sevilla ${ }^{6}$.

3. VAN DER HAMmen y León, Lorenzo: Via Sacra, su origen y disposición y lo que se deve meditar en ella..., Granada, 1656, hoj. 1 vta.

4. Ibidem, hoj. 4 vta.

5. Reflexiones clásicas en GIL, C.: «España ¿cuna del Vía Crucis?», Archivo Iberoamericano, 11 (1951) y actualización por extenso en HuERGA, Álvaro: Escalaceli, Madrid, 1981.

6. Martín de la Torre, Antonio: «Vía Crucis a la Cruz del Campo. Estudio arqueológico e histórico de una devoción sevillana», Archivo Hispalense, 51-52 (1952), pp. 49-104; GonzÁLEz Moreno, Joaquín: Vía Crucis a la Cruz del Campo, Sevilla, 1992, y RodA PeÑa, José et al.: El Humilladero de la Cruz del Campo y la religiosidad sevillana, Sevilla, 1999. Otros análisis para el área hispalense en publicaciones locales: GonzÁlez Moreno, Joaquín: «Los orígenes del Vía Crucis a la Cruz del Campo», Boletín de las Cofradías de Sevilla, 475 (1998) y CAMPa CARmona, Ramón de la: «El Víacrucis: un ejercicio de piedad aquilatada a lo largo de los siglos», Boletín Informativo del Consejo de Hermandades y Cofradías de Dos Hermanas, 73 (2005). 
El trazado de estos caminos requería, además de las licencias eclesiásticas y municipales, la sanción de la orden franciscana, que ejercía una función tutelar sobre la práctica de la vía sacra, ya que en definitiva se había encargado de promoverla y extenderla, hallándose presente en la erección de los itinerarios, como queda de manifiesto en la licencia concedida por fray Pedro de Baltodano, guardián del convento de S. Antonio de Padua (franciscanos descalzos) a la granadina hermandad de S. Miguel:

«Por cuanto los religiosos de nuestro padre San Francisco tenemos authoridad y facultad concedida de muchos Sumos Pontífices para elegir y señalar sitios y caminos, así públicos como secretos, para que todos los fieles anden y frequenten el vía crucis en memoria de los pasos que anduvo para nuestra redempción nuestro Redemptor Jesucristo, a petición y súplica de tan devota como piadosa hermandad asigno y señalo, por pribilegio que tengo pontificio, el camino que sube a la hermita de San Miguel y los sitios donde estubieren colocadas las cruzes para el devoto exercicio de andar la vía sacra. Y así mismo doy estas mis letras con todas las circunstancias, fines y motibos que an tenido los Sumos Pontífices en concedernos este pribilegio y tantas gracias e indulgencias como están concedidas para los que se ocuparen en el dicho y deboto exercicio»?

Lo que en origen se trataba de un medio para asegurar la fidelidad de las medidas de la senda y la adecuación al escenario hierosolimitano, acabó redundando en una expresión de prestigio de la orden franciscana, a la vez que de extensión de sus reclamos devocionales, que encontraron un buen filón en torno a la Pasión de Jesucristo. Los itinerarios de las vías sacras solían comenzar en puntos de la periferia de la ciudad y se extendían, alejándose de ella, hasta parajes campestres y elevados, para acentuar el sentido de subida y sacrificio, de purificación del alma, en definitiva, de ascesis personal.

Era esencial ese carácter ascensional en estos recorridos, razón por la que concluían en lugares elevados, como ocurría en los enclaves granadinos del cerro de $\mathrm{S}$. Miguel, cerro de S. Antonio, campo de los Mártires, cerro de los Rebites y, de una manera especial, el Monte Santo de Valparaíso. Con especial precisión se contaban y señalaban los pasos entre una estación y otra, tratando de reconstruir de la manera más exacta posible el itinerario de la Ciudad Santa, a la que por otra parte se comparaba Granada en la abundante literatura apologética ${ }^{8}$.

Fray Bernardino Caimo, franciscano, reprodujo en el monte Verallo, cerca de Milán, los lugares de Jerusalén cuando corría el siglo XV. Paso a paso, se fue configurando el ejercicio del vía crucis, contándose entre sus más célebres propagadores en España fray Álvaro de Córdoba, incluso antes que Caimo, y en Italia, tres siglos más tarde, Leonardo de Porto-Maurizzio. En Granada, por su especial carga simbólicomesiánica y lo escarpado de su orografía, acabó conformándose esta costumbre de la

7. Núñez Contreras, Luis: La Hermandad de San Miguel de Granada, Granada, 1963, pp. 122-123.

8. Vid. las reflexiones de Calatrava, Juan: «Encomium Urbis: La Antigüedad y Excelencias de Granada (1608) de Francisco Bermúdez de Pedraza», en Cortés PeÑa, A. L., López-Guadalupe Muñoz, M. L. y Lara Ramos, A. (eds.): Iglesia y sociedad en el reino de Granada (Ss. XVI-XVIII), Granada, 2003, pp. 467-485. 
vía con la tradición italiana de los montes santos ${ }^{9}$. Esto añadía un valor más trascendente al ejercicio, porque del sólo ascenso a cerros como el del Sacromonte o el de los Mártires se esperaban beneficios taumatúrgicos y un especial amparo de la divinidad. No se olvide en el primer caso la «invención» de las reliquias de mártires de los primeros tiempos del cristianismo ${ }^{10} \mathrm{y}$, en el segundo, el recuerdo de los cristianos que sufrieron áspero cautiverio durante la Granada nazarí1 ${ }^{11}$.

\subsection{El ejercicio de la vía sacra}

Este ejercicio suponía una rememoración de la Pasión en toda su extensión, sazonada con el valor añadido de la peregrinación, la penitencia y la ascesis espiritual. A diferencia de las cofradías penitenciales, los hermanos de la vía sacra no veneraban un misterio concreto -aunque estas cofradías tuvieran una imagen titular determinada o se reverenciara a diversas imágenes en las capillas que jalonaba la «calle de la amargura»-, sino que meditaban sobre la Pasión completa. Aún más, la senda de penitencia, concluida en la ermita del Sto. Sepulcro, se completaba con algunas oraciones jubilosas, en memoria de la Resurrección, y con diversos rezos marianos en el descenso. Era una forma particular de asentar el espíritu de conversión, en una transformación espiritual en la que claramente se pasa de la muerte a la vida, todo ello bajo un horizonte simbólico de gran calado, donde la realidad martirial añade una emotividad nada desdeñable. De este modo, el Monte Santo es una representación de la Nueva Jerusalén y, como tal, testimonia la Resurrección de Cristo, «pues toda reliquia conformará el cuerpo de Jesucristo en la gloriosa Resurrección», según el pensamiento de Sto. Tomás ${ }^{12}$.

Todas estas vías sacras tuvieron unos orígenes sencillos. Eran congregaciones minoritarias; en algunos casos reducidas a doce miembros, encargados de recorrer el camino y de realizar las estaciones, buscando la conversión personal, pero a la vez el testimonio ejemplarizante. Cuando tenían lugar en Cuaresma, no era raro que los hermanos se disciplinaran, aunque por lo común no a la vista del público, lo que parece bastante extendido en el siglo XVII. No se trataba, en puridad, de un acto colectivo, como el protagonizado por las cuadrillas de disciplinantes en las procesiones de Semana Santa, tan denostadas por la autoridad eclesiástica ${ }^{13}$, sino más bien la expre-

9. Bonet Correa, Antonio: «Entre la superchería y la fe: el Sacromonte de Granada», en Andalucía monumental. Arquitectura y ciudad del Renacimiento y del Barroco, Sevilla, 1986, pp. 31-52.

10. Entre la extensa bibliografía al respecto sobresalen las obras recientes de BARrios AguiLERA, Manuel y García-Arenal, Mercedes (eds.); Los plomos del Sacromonte. Invención y tesoro, Valencia, 2006, y ¿La historia inventada? Los libros plúmbeos y el legado sacromontano, Granada, 2008.

11. Cfr. SÁnchez-Montes GonzÁlez, Francisco: «El Realejo», en Nuevos paseos por Granada y sus contornos, Granada, 1992.

12. En Orozco Pardo, José Luis, Christianópolis: Urbanismo y Contrarreforma en la Granada del Seiscientos, Granada, 1985, p. 107.

13. LóPeZ-Guadalupe Muñoz, Miguel Luis: «La estación de penitencia en la Granada del siglo XVIII: de la disciplina pública a la exaltación de la imagen», en Actas del III Congreso Nacional de Cofradías de Semana Santa, Córdoba, 1997, vol. I, pp. 119-138. 
sión de un sentimiento de expiación personal. Pero en su dimensión pública sí que coincidían con las cofradías penitenciales. Y es que las vías sacras extendieron la actividad procesional al conjunto de la Cuaresma -generalmente los viernes-, pero también practicaron este ejercicio público en otras épocas del año, institucionalizando aún más la devoción del vía crucis.

En Granada, el paradigma lo representan los hermanos de la vía sacra de Valparaíso. Éstos no eran sino un grupo de terceros del convento de S. Francisco Casa Grande, que iniciaron la costumbre de la vía sacra hacia 1633. Se trata, por tanto, de una asociación de intereses primordialmente espirituales, que transfería a la vida de los seglares, mediante símbolos, ritos, gestos y actitudes, el carisma propio del franciscanismo ${ }^{14}$. Su corporación de vía sacra contó en Granada con terceros ilustres, que gozaban de gran reputación, como el apaciguador de los motines de mediados del seiscientos, Luis de Paz y Medrano (1604-1667) $)^{15}$, miembro de esta Orden Tercera de Penitencia de S. Francisco; frecuentaba cada viernes las estaciones de este vía crucis, aunque lo había hecho a diario mientras se lo permitió su salud. Rodeado en vida de un halo de caridad y santidad, pasaba horas con una soga alrededor del cuello, meditando ante una imagen del Ecce-Homo y tuvo una aparición del mismo Cristo en el Sacromonte granadino, justamente cuando vestía el prócer su «hábito de penitencia nazareno» ${ }^{16}$.

Gracias a la pormenorizada obra de Van der Hammen conocemos el desarrollo del ejercicio y su ceremonial ${ }^{17}$, tal y como lo practicaban los terciarios franciscanos:

a) Fase de preparación:

Se realizaba en la iglesia de los Stos. Pedro y Pablo, junto al río Darro, comenzando con un acto de arrepentimiento y el rezo de la oración «Nada soy Dios mío...», a lo que seguía el recuerdo de los últimos días de la vida de Jesús (llegada a Jerusalén, última cena, lavatorio, institución de la Eucaristía, oración en el huerto de Getsemaní, prendimiento, comparecencia ante Anás, Caifás, Pilato y Herodes, azotes, coronación de espinas, sentencia de muerte y entrega de la cruz), concluyendo con una oración. Nótese, por tanto, que la mayor parte del proceso pasionista se rememoraba a través de la Palabra y no mediante la contemplación de obras de arte (pinturas y esculturas) o dramatizaciones pseudo-teatrales. A continuación, los hermanos se persignaban ante el Santísimo e invocaban al Espíritu Santo, para terminar esta fase con un acto de confesión general y el rezo del «Yo pecador» y del «Señor mío, Iesu Christo», oración con la que se ganaban cuarenta días de indulgencia.

14. Vid. la obra clásica de Amberes, Fredegando de: La tercera orden secular de San Francisco (1221-1921), Barcelona, 1925, el detallado estudio de Meersseman, Gilles Gerard: Ordo fraternitatis. Confraternite et pietá dei laici nel Medioevo, Roma, 1977, 3 vols., y la obra colectiva de PeláEz del Rosal, Manuel (coord.): El Franciscanismo en Andalucía: la orden tercera seglar, Córdoba, 2006.

15. Detalles del motín en Domínguez OrTiz, Antonio: Alteraciones andaluzas, Madrid, 1973, pp. 55-64.

16. Jesús, Fr. Antonio de: Epitome de la admirable vida del ilustre varón don Luis de Paz y Medrano..., Granada, 1688, p. 114.

17. Van der Hammen y León, L.: Vía Sacra..., op. cit., hh. 8 vta.-68 vta. 
b) Estaciones previas:

Eran tres estaciones que, para poner en situación, se realizaban antes de llegar hasta la imagen de Ntra. Señora (probablemente en la cuesta del Chapiz, en las casas del mismo nombre, en las que fugazmente había un monasterio de franciscanas tan sólo cinco años antes ${ }^{18}$ ), punto en el que comenzaba realmente la vía dolorosa que seguía el camino del Sacromonte. Estas estaciones, con sus correspondientes oraciones, se ofrecían por los que estaban en pecado mortal, por las almas del purgatorio y por la Iglesia Católica, respectivamente, terminando, como puede observarse, bajo el patrocinio de la Virgen María, llamada a acompañar en todo momento al cristiano que se acercara a la ladera del Calvario, como hiciera en su día en Jerusalén. Este era el momento, si no se había hecho en el templo, de aplicar todo el ejercicio para determinadas intenciones, con el rezo de una estación del Santísimo (seis padrenuestros, avemarías y glorias), con que se ganaban las mismas indulgencias que en la Porciúncula, Roma, Jerusalén y Santiago. Como se observa, tampoco podía faltar la devoción sacramental.

c) Vía dolorosa:

Constaba de catorce estaciones, en cada una de las cuales se obtenían treinta indulgencias plenarias y se sacaban dos ánimas del purgatorio, cumpliendo ciertos requisitos. En total -nos recuerda Van der Hammen- «vienen a ser quatrocientas y veinte indulgencias plenarias y veinte y ocho Almas de Purgatorio. Esto se entiende siendo Religioso, Hermano de la Tercera Orden de Penitencia o Cofrade del Cordón de nuestro Seráfico Padre, y teniendo la Bula de la Santa Cruzada. No lo siendo, ganas cien días de indulgencia, no más». Curiosa matización que refuerza aún más el sesgo oficialista de este ejercicio, en el que el principio de jerarquía resplandece con luz propia, por no hablar del singular valor de las gracias espirituales que podían obtenerse, un reclamo, poderoso sin duda, para fieles más exigentes en cuestiones de práctica religiosa. Una meditación sobre el pasaje de la pasión correspondiente y una oración de ofrecimiento, con adoración de rodillas ante la cruz que la señalaba, componían cada estación. Se sucedían con las siguientes distancias:

1. Estancia ante Pilatos en el Pretorio. Meditación sobre los azotes, coronación de espinas, burlas y escarnio, presentación al pueblo, sentencia, etc.

2. La cruz es puesta sobre los hombres de Jesús (a 26 pasos).

3. Primera caída (a 80 pasos).

4. Encuentro de Jesús con la Virgen y S. Juan (a 60 pasos y 3 pies).

5. Simón de Cirene ayuda a llevar la cruz (a 61 pasos y 1,5 pies).

6. La Verónica enjuga el rostro de Jesús (a 91 pasos y medio pie). Reflexión sobre la Sta. Faz.

18. Fue la sede pasajera del convento del Sto. Ángel (vid. LóPEZ-GuAdalupe MuÑoz, Miguel Luis y López Moya, Rafael: «Vida y hagiografía de Sor María de las Llagas, la fundadora-marquesa del convento del Ángel Custodio de Granada», en Peláez del Rosal, Manuel (coord.): El Franciscanismo en Andalucía: perfiles y figuras del franciscanismo andaluz, Córdoba, 2009. pp. 242-243). 
7. Segunda caída, en la Puerta Judiciaria (a 336 pasos y 2 pies).

8. Alocución a las mujeres de Jerusalén (a 348 pasos y 2 pies).

9. Tercera caída en la falda del Calvario (a 161 pasos y 1,5 pies).

10. Despojo de las vestiduras (a 18 pasos). Meditación sobre la desnudez de Jesús, su ofrecimiento de la Pasión, etc.

11. Jesús clavado en la cruz (a 12 pasos).

12. Crucifixión y muerte en la cruz (a 14 pasos). Consideraciones sobre la sangre de Cristo, el letrero sobre la cruz $^{19}$, las siete palabras, la expiración o la lanzada.

13. El cuerpo de Jesús es depositado en los brazos de María (a 13 pasos). Meditaciones sobre María en el Calvario y el descendimiento de Jesús.

14. Jesús amortajado a la puerta del sepulcro (a 30 pasos).

Las meditaciones se realizaban con el dramatismo propio de la elocuencia barroca, acentuando los padecimientos de Jesús y los dolores de su Madre, como síntesis vivencial de todo lo contemplado a lo largo de las estaciones.

d) Ejercicios finales:

Se desarrollaban una vez terminada la senda dolorosa, en el mismo Sacromonte, comenzando con la visita de los hornos martiriales -cuyas reliquias testimoniaban con su lacre de sangre la veracidad del Evangelio y el poder de Dios-, rezando por el camino tres salves y una estación del Santísimo. Ya en los hornos, y de rodillas, se hacía oración de alabanza, se rezaba el padrenuestro y se repetía tres veces la palabra «Jesús» (obteniendo mil años de indulgencia por cada vez). A continuación se visitaba la iglesia de la abadía, entonando una nueva oración de alabanza al Santísimo y a la Virgen María, el padrenuestro y el avemaría (para ganar indulgencia plenaria), a lo que seguía una plática por uno de los canónigos, disciplinas y mortificaciones, así como la oración del santo sudario (para sacar un alma del purgatorio), concluyendo con una nueva oración. Esta etapa del ejercicio se considera fundamental, destacando dos aspectos: en primer lugar, la intervención clerical encarnada en miembros de la institución sacromontana, especializada, entre otros cometidos, en misiones populares destinadas a conmocionar al pueblo fiel ${ }^{20}$; en segundo, por la práctica de una autoflagelación recoleta y controlada, alejada del espacio amplificador de la calle y más cercana a la mortifica-

19. Se decía por entonces que el INRI había aparecido justamente el 2 de enero de 1492 en la romana basílica de Sta. Cruz en Jerusalén (NaTividad, Fr. Manuel de la: Encantos divinos y humanos de Granada en su restauración y toma gloriosa..., Granada, 1701).

20. Cfr. Barrios Aguilera, Manuel: «Las misiones en la sociedad posrepobladora: las del Sacromonte de Granada», en Barrios Aguilera, M. y Galán Sánchez, A. (eds.): La Historia del Reino de Granada a debate. Viejos y nuevos temas. Perspectivas de estudio, Málaga, 2004, pp. 551-593. 
ción doméstica que, por ejemplo, prescribían para las mujeres cofrades, en la noche del Jueves Santo, las ordenanzas de la granadina Cofradía de la Vera Cruz ${ }^{21}$.

e) Regreso:

Como colofón a este piadoso ejercicio de la vía sacra se regresaba a la ciudad, recitando por el camino la Corona de Nuestra Señora, por la que se obtenían nuevas $\mathrm{y}$ abundantes indulgencias. El proceso es claro, aislarse del mundo para alcanzar un vigor espiritual, con el que regresar de nuevo al mundo; este era, sin duda, el valor trascendente del periplo de alejamiento y posterior retorno a la ciudad (esto es, lo mundano); una concepción muy cercana al espíritu de las órdenes religiosas y, en particular, a la naturaleza intrínseca del monacato. Algunos de esos elementos se mantienen aún en expresiones religiosas actuales de alto nivel devocional y etnográfico ${ }^{22}$.

Sigamos abundando en el contrapunto con las cofradías penitenciales o de Semana Santa. Si éstas practicaron una penitencia pública, también la penitencia era el móvil principal de las congregaciones de vía sacra, pero con una dimensión y profundidad diferentes, que exigían compromisos personales, inspirados desde una decidida dirección espiritual. En este contexto, no extraña que se trate de asociaciones selectas, tanto en el número de hermanos como en general en el de fieles que asisten, con un trasfondo claramente espiritual. Lo que sí es seguro es que tuvieron su etapa dorada en el siglo XVIII, en Granada y en otras localidades ${ }^{23}$.

\subsection{Itinerarios granadinos de vía sacra}

Ese carácter más restringido, la sacralización de espacios exteriores en el tiempo litúrgico de Cuaresma y la manifestación penitencial controlada constituyen las claves para entender esta tipología asociativa. La escasez de datos, sin embargo, impide conocer la vitalidad de las, al menos diez, cofradías de este tipo (a las que tal vez podrían añadirse algunas más de las numerosas cofradías que, sin ser penitenciales, florecieron en torno a advocaciones e imágenes pasionistas en la Granada dieciochesca ${ }^{24}$ ). Sí que se conocen los cinco itinerarios que recorrían, adentrándose por los alrededores de la ciudad:

21. LóPeZ-Guadalupe MuÑoz, Miguel Luis: «Orígenes de las cofradías penitenciales granadinas: la fundación de la Vera Cruz», en Cortés Peña, A. L., López-Guadalupe Muñoz, M. L. y Lara Ramos, A. (eds.): Iglesia y sociedad en el reino de Granada (Ss. XVI-XVIII), Granada, 2003, p. 363.

22. Vid. García RodríGuez, Jesús María: «El Vía Crucis de la Semana Santa en Galera», Boletín del Instituto de Estudios Pedro Suárez, 5 (1992), pp. 87-102.

23. A título de ejemplo, Amores Martínez, Francisco: «Las Confraternidades del Vía Crucis en Sevilla (siglos XVIII-XIX)», en Actas del IV Congreso Nacional de Cofradías de Semana Santa, Salamanca, 2002 .

24. Como la de Jesús de la Agonía en la parroquia de S. Andrés, la del Cristo de los Trabajos en Las Angustias o la Vía Sacra y S. Antonio de Padua de S. Bartolomé. 


\section{1) Sacromonte}

Era la más antigua, pues su creación data de las peregrinaciones de los fieles granadinos para venerar las reliquias martiriales de $\mathrm{S}$. Cecilio y sus compañeros, a finales del siglo XVI, momento en el que el paraje quedó plagado de cruces, levantadas por la devoción de los fieles, cuya retirada se vio forzada a decretar la autoridad eclesiástica ${ }^{25}$. El itinerario quedó definitivamente marcado con cruces de piedra alrededor de 1630. El cronista local Francisco Henríquez de Jorquera pondera la grandeza de las cruces, pero sólo en tanto que hitos en la senda dolorosa: «Tenga el primer lugar en cuanto cruces el Sacromonte Ilipulitano y la Sacra vía de los Terceros de la gran casa de nuestro seráfico san Francisco, que comienza desde las principales casas del Chapiz y acaba en el monte Calvario y Resurrección de Nuestro Señor Jesucristo» ${ }^{26}$. En la erección de las cruces se afanaron nobles, ricos y trabajadores, a veces de forma colectiva, como reza en esta inscripción: «Los Ganapanes en dones / Dieron al Monte Sagrado / Esta Cruz, siendo Prelado / Don Pedro Castro y Quiñones». Era la levantada por los integrantes de la hermandad de Nuestra Señora y Ánimas, de «ganapanes» o «esportilleros», sita en la parroquia de la Magdalena, a la que curiosamente perteneció también Luis de Paz y Medrano, a pesar de su elevada condición social. Gesto de humildad, pero a la vez signo de distinción, de forma que, «sentado entre ellos, vermejeava la roxa cruz de Calatrava entre los pardos vestidos de tan humilde gente, como el sol quando se pone entre nubes pardas» ${ }^{27}$.

Frecuentaba este itinerario la Orden de Penitencia del convento de S. Francisco, llamado Casa Grande, por ser el centro de la provincia franciscana. A ella acudían los hermanos todos los viernes del año y en cuaresma también los miércoles.

\section{2) San Antón}

Esta vía sacra discurría a orillas del río Genil y se había erigido por los frailes terceros del convento de S. Antonio Abad. Tenía su comienzo en la ermita del Pretorio, donde se veneraba la imagen de Jesús de la Humildad y los Trabajos, bajo la siguiente inscripción en su puerta: «Esta Vía sacra es de la piadosa Congregación de los Trabajos de Jesús $»^{28}$, lo que permite suponer que la utilizó en sus orígenes la hermandad del Cristo de los Trabajos (radicada en la parroquia del Sagrario). El trinitario Lachica la define como «muy hermosa» y «está con grande decencia en ella el Santo Christo de la Humildad y Trabajos, que es de los más devotos simulacros que se adoran en este pueblo» ${ }^{29}$. Tras dejar atrás otra antigua ermita, la de S. Antón (el Viejo), terminaba en

25. Hasta 1.200 cruces (Gómez de LiAÑo, Ignacio: Los juegos del Sacromonte, Madrid, 1975, pp. 215-216).

26. Henríquez de Jorquera, Francisco: Anales de Granada, Granada, 1934 (ed. facsímil, Granada, 1987), vol. I, pp. 267-268.

27. Jesús, Fr. A. de: Epitome.., op. cit., p. 63.

28. Gallego Burín, Antonio: Granada. Guía artística e histórica de la ciudad, Granada, 1982, p. 195.

29. Lachica Benavides, Fr. Antonio de: Gazetilla curiosa o Semanero granadino..., Granada, 1764-1765, papel LVIII, hoj. 3 vta. 
la del Sto. Sepulcro del cerro de los Rebites, adornada con las imágenes del Nazareno y la Soledad, así como un lienzo del Descendimiento. Las capillas de este itinerario se construyeron entre 1661 y 1667.

Realizaba su vía crucis por este itinerario la Orden Tercera de Penitencia del convento de S. Antonio Abad, y tal vez también la citada cofradía del Cristo de los Trabajos en alguna etapa de su existencia a lo largo del siglo XVIII.

\section{3) Campo de los Mártires}

Se trataba también de un lugar sagrado, al estimarse que allí tuvieron lugar los martirios de los cristianos - como fray Pedro Nicolás Pascual, fray Pedro de Dueñas o fray Juan de Cetina- durante la ocupación musulmana: «los Christianos Conquistadores de Granada -escribe de nuevo Lachica-calificaron a este Cerro por sagrado, y decían, que se debía subir a él de rodillas» ${ }^{30}$. Tenía por conclusión el convento de los Mártires, cuya organización originaria, incluidas las devociones pasionistas emanadas de él, estuvieron muy inspiradas por la personalidad de la S. Juan de la Cruz, que fue su prior $^{31}$.

La hermandad del Cristo de los Trabajos (parroquia del Sagrario) concurría a esta vía sacra: «están obligados por voto particular a subir a el Convento de los Santos Mártires, en Vía Sacra, en acción de gracias por la salud que recibió esta Ciudad en la Epidemia del año 1679»»32. También la frecuentaban las hermandades del Cristo de la Expiración (ante cuya imagen «se hace disciplina los viernes de cuaresma y se canta el miserere con grande música y se gana indulgencia en su capilla ${ }^{33}$ ), Cristo de la Esperanza y Cristo de las Penas, establecidas respectivamente en las iglesias de S. Gil, La Magdalena y Sta. Cruz la Real (convento de dominicos).

\section{4) Cerro del Aceituno o de San Miguel}

Coronado con la ermita dedicada al Arcángel, se erigió en vía sacra en 1756 y las cruces fueron costeadas por la hermandad de S. Miguel. Con trazado típicamente albaicinero, comenzaba en la plaza de la Cruz de Piedra y terminaba en la ermita.

Realizaba el vía crucis en este enclave la Vía Sacra unida a la hermandad de S. Miguel.

30. Ibidem, papel XXVIII, hoj. 1 vta.

31. Szmolka Clares, José: «La religiosidad popular granadina y San Juan de la Cruz», en IV Centenario de la muerte de San Juan de la Cruz, Jaén, 1992, pp. 187-201; detalladamente en LóPez-GuAdaLuPE MuÑoz, Juan Jesús: «Mística y naturalismo. Pablo de Rojas, San Juan de la Cruz y el Nazareno de los Mártires de Granada», en Imágenes elocuentes. Estudios sobre patrimonio escultórico, Granada, 2008, pp. 303-344.

32. Lachica Benavides, Fr. A. de: Gazetilla..., op. cit., papel XVIII, hoj. 2.

33. Henríquez de Jorquera, F.: Anales..., op. cit., vol. I, p. 222. 


\section{5) Ciudadela de la Alhambra}

En las primeras décadas del siglo XIX, y quizás algo antes, se utilizaba una vía sacra establecida en la fortaleza, desde la parroquia de Sta. María hasta la ermita del Sto. Sepulcro, edificada en la parte alta de la ciudadela (Secano), a espaldas del convento de S. Francisco de la Alhambra, de franciscanos observantes.

Era la frecuentada por la cofradía de Jesús de la Humildad y Stmo. Cristo de la Vía Sacra ${ }^{34}$. Tal vez esta vía vino a sustituir a la del Campo de los Mártires, posiblemente en desuso en esas fechas ya tardías.

\section{6) San Diego}

Es la menos conocida de todas y se sitúa en el sector septentrional de la ciudad, en torno al convento de franciscanos descalzos de S. Antonio de Padua y S. Diego de Alcalá. Tal vez comenzara en la parte llana del barrio, en torno a la parroquia de $\mathrm{S}$. Ildefonso, para subir hasta el citado cenobio, hoy desaparecido.

Parece lógico pensar que recorrerían esta senda dolorosa los hermanos terceros de dicho convento de alcantarinos, así como la tardía Vía Sacra de la Casa de Recogidas.

\section{EVOLUCIÓN DEL MODELO DE VÍA SACRA DESDE EL SIGLO XVIII}

\subsection{El avance de la barroquización y la conflictividad}

La vía sacra ofrecía la posibilidad de una penitencia personal, practicada en comunidad o individualmente, en una bella conjunción con la naturaleza. Por tanto, su práctica devenía en comunitario ejercicio de hermandad o en ascética mortificación personal. Curiosa amalgama de lo que ha dado en llamarse religiosidad popular y religiosidad devocional ${ }^{35}$. Los cortejos de las vías sacras eran simples: los hermanos -por lo general, hermanos de luz, sin descartar la presencia de disciplinantes-, a lo sumo el estandarte y tal vez la imagen de un Crucifijo a la cabeza, sobre sencillas andas o más bien en las manos de algún fraile o clérigo. Dado su discurrir con frecuencia nocturno y por lugares apartados, el uso de cirios o de faroles se hizo indispensable.

Sin embargo, el paso del tiempo introdujo un patrimonio más rico y diversificado. Basta con una ojeada al inventario de la hermandad del Cristo de la Esperanza, fechado en 1768. Se advierte el enriquecimiento de los enseres dispuestos para la vía sacra: imagen del Sto. Cristo pequeña, con cruz, corona y potencias de plata; peana para llevar el Sto. Cristo; sudarios para dicha imagen, tres dorados, uno morado y otro blanco; ocho faroles, uno más de mano, una cruz de madera de color verde y oro; un estandarte de damasco dorado, con vara y remate de plata; una campanilla y una cesta

34. Archivo Eclesiástico de la Curia de Granada (A.E.C.G.), leg. 14F(A), pza. 2(8).

35. Vid. al respecto CASTÓN Boyer, Pedro: «La religiosidad tradicional en Andalucía. Una aproximación sociológica», en La religión en Andalucía, Barcelona, 1985, p. 105. 
de mano, cirios y las llaves para abrir la iglesia de los Mártires ${ }^{36}$, ermita o capilla aneja al cenobio de los carmelitas descalzos, en la que acababa el ejercicio piadoso. Además adornaban su capilla, en la parroquia de La Magdalena, junto al Cristo, las imágenes de la Virgen, S. Juan y María Salomé ${ }^{37}$.

Las imágenes titulares de estas populares cofradías, cuando las había, recibieron culto preferentemente en las funciones celebradas en sus templos-sede. De este modo, culto solemne y ejercicio piadoso se complementaban a la perfección. Si se admite esa consideración de las vías sacras como una alternativa, más austera y depurada, a las cofradías de penitencia, hay que aceptar que representaban el deseo de una vuelta a los orígenes, como tantas otras iniciativas de reforma en materia religiosa.

Pero lo cierto es que con el tiempo estas cofradías también se «urbanizaron» y organizaron cortejos procesionales típicamente barrocos, donde no faltaba la imagen religiosa puesta en andas. Ya en el siglo XVIII existen referencias de la lucida procesión del Cristo de la Expiración (iglesia de S. Gil), con abundancia de hermanos de luz y de horquilleros ${ }^{38}$. Presentaba un cortejo propio de cualquier estación penitencial barroca, con la salvedad de que no se desarrollaba durante la Semana Santa, sino en algún día de Cuaresma. Estamos, pues, ante otro ejemplo de «cofradía barroca» ${ }^{39}$, sintomático del cambio operado en esta tipología de cofradías en relación con la práctica penitencial sincera y austera que dominó en sus principios. Es la clara expresión de la superioridad de las fórmulas procesionales de las cofradías de penitencia, que siempre gozaron del favor popular.

Por consiguiente, estas cofradías acabaron moviéndose en los mismos parámetros formales que las demás cofradías. Para colmo, no faltaron roces entre ellas. Cuando en 1721 un grupo de feligreses de La Magdalena intentó fundar su vía sacra con el título de Cristo de la Expiración, se encontraron con la cerrada oposición de los cofrades de la Vía Sacra de la iglesia del Sagrario (Cristo de los Trabajos), de gran antigüedad, así como la del Cristo de la Expiración de S. Gil. Esta es la razón por la que la nueva hermandad hubo de fundarse finalmente bajo el título del Stmo. Cristo de la Esperanza. Y la causa no era otra que el reconocimiento popular de ambas intitulaciones -Vía Sacra y Expiración-, que hacía peligrar la consecución de limosnas por parte de las otras dos hermandades, o al menos así lo creyeron y sostuvieron sus respectivos cofrades.

Como todas, las cofradías de vía sacra se encontraban bajo la jurisdicción eclesiástica, si bien el hecho de residir algunas de ellas en conventos o en ermitas les daba cierta autonomía, como ocurría con la de S. Miguel, que trató de atajarse de forma fulminante. En 1768, el capellán de la ermita, Antonio Gadeo, denunció a la herman-

36. Archivo de la Parroquia de la Magdalena (A.P.M.), caja 48.

37. Vid. sobre esta hermandad LóPEz MuÑoz, Miguel Luis: Las cofradías de la parroquia de Santa María Magdalena de Granada en los siglos XVII-XVIII, Granada, 1992, pp. 126-128.

38. A.E.C.G., leg. 17F, pza. 60, ff. 9 vto.-10, año 1741.

39. Reflexiones sobre este modelo en SÁnchez Herrero, José: «Las cofradías de Semana Santa de Sevilla durante la Modernidad. Siglos XV a XVIII», en Las cofradias de Sevilla en la Modernidad, Sevilla, 1988, pp. 27-97. 
dad ante el Consejo de Castilla, por varios motivos, como profanidades, realización de actos sin licencia, etc., dejando traslucir la animadversión del capellán. Para su alegación recurrió al argumento jurisdiccional que tanto preocupaba a la administración regalista de Carlos III:

«Los capellanes se nombran por el muy reverendo Arzobispo, pero haviendo éstos querido reprehender y remediar algunos de los herrores que adbierten en los hermanos, se han conspirado contra ellos, tratándolos vilipendiosamente de obra y de palabra con injuria y bulneración de su carácter sazerdotal, hasta haver logrado separar al anterior y aún a mi parte pretenden azer lo mismo, mediante los medios violentos que ejecutan, por quanto su ydea es dominar aquel sitio con tal despotismo sin dependencia ni subordinación a nadie, guarecidos con la jurisdicción privativa de la Halambra, como terreno perteneciente a ella, por cuio respecto y evitar competencias se escusa el muy reverendo Arzobispo a tomar providencias en algunos asuntos, de forma que los hermanos y cofadres, quando les conbiene, se acojen al fuero eclesiástico por hermandad para que no se atreba a prozeder contra ella ni incluirse en sus operaciones la jurisdicción real y, quando les es útil, evadir la juridicción de la Alhambra, yludiendo por este medio a todas porque su ánimo es en clase de cofradía y hermandad no bibir sugetos a lexítima potextad alguna, usurpando los derechos y regalías de la Mitra» ${ }^{40}$.

La consecuencia no fue otra que la inmediata extinción de la hermandad, a lo que contribuyó el hecho de poseer sólo la aprobación eclesiástica y no la real. Lejos quedaban los recatados y modosos orígenes de las congregaciones de vía sacra. En este caso prevaleció el altivo «espíritu de cofradías» al que aludió Pablo de Olavide ${ }^{41}$.

La misma peculiaridad jurisdiccional castrense se rastrea en la hermandad de Jesús de la Humildad, establecida en la iglesia de Sta. María de la Alhambra. Sólo que la aducen en sentido contrario: cuando en 1827 el Gobernador de la fortaleza intervino en algunos asuntos de la cofradía, ésta reclamó inmediatamente a la jurisdicción eclesiástica, alegando que se trataba «no de cosa profana y sí de una hermandad establecida en la Iglesia y es notorio que en tales casos no pueden ser jueces los seculares $\rangle^{42}$.

\subsection{Via Sacra de Recogidas: una fundación tardía}

Un episodio tardío y pasajero, enmarcado en el contexto histórico del Trienio Liberal, nos ayudará a ilustrar la deriva que habían tomado estas fundaciones de vía sacra y la encrucijada en la que se hallaban. La Vía Sacra de la Casa de Recogidas de Granada será la protagonista del tramo final de este estudio. De entrada, se trata de una sede inusual, pues es bien sabido que el beaterio era un centro donde se internaba a

40. En NúÑez Contreras, L.: La Hermandad..., op. cit., p. 147.

41. En Arias de SaAvedra Alías, Inmaculada y López-Guadalupe Muñoz, Miguel Luis: La represión de la religiosidad popular. Crítica y acción contra las cofradías en la España del siglo XVIII, Granada, 2002, p. 345.

42. A.E.C.G., leg. 14F(A), pza. 2(10). 
mujeres quitadas del comercio público y pecaminoso de la carne ${ }^{43}$. No es ya el deseo de elevación de unos religiosos que tratan de seducir a sectores elitistas de la sociedad, ni tampoco la proyección parroquial de estrategias de encuadramiento y control de los fieles dentro de los límites de la más escueta evangelización. En este caso prima lo estrictamente popular.

Fueron sus capellanes-fundadores dos frailes franciscanos, aunque de distintas comunidades. Fr. Francisco de Paula Molina moraba en el inmediato cenobio de S. Antonio Abad, de terceros franciscanos, y Fr. Francisco Estévanez pertenecía al convento de S. Antonio de Padua, de franciscanos descalzos. Ambos eran los garantes de la correcta realización de la vía sacra, cuyo control y supervisión (sobre todo las estaciones y medidas coincidentes con la hierosolimitana «calle de la amargura»), como se indicó, se encontraba en manos de los frailes franciscanos. Máxime cuando sus respectivos conventos regentaron dos de las vías sacras granadinas ya señaladas: la de S. Antón el Viejo y la de S. Diego.

Junto a ellos, encabezan esta aventura una mujer -situación también inusual-, la responsable del «centro de internamiento», es decir la rectora del beaterio, Luisa María del Carmen, y el seglar Antonio Salvador Fernández, que puede considerarse el alma mater de la fundación confraternal, siendo su primer hermano mayor, a la vez que residía en la vecina calle de la Monterería. Dio comienzo la fundación el 17 de junio de 1821, domingo de la Stma. Trinidad (otra de las devociones del barrio, ya que S. Antón y La Trinidad se ubicaban en ambos extremos de la calle de la Alhóndiga). Pero sus orígenes se rastrean ya al menos desde el Día de Todos los Santos de 1819 en el convento de S. Antón. Una práctica habitual, pues las cofradías suelen anteponer un «rodaje» variable a su decidida instauración formal ${ }^{44}$.

Hábilmente completaron el título de Vía Sacra con el de «hermandad de la hospitalidad». Debieron pesar dos razones: la primera, su ubicación en un centro «asistencial», a cuyo mantenimiento podían contribuir, practicando en él la virtud de la caridad; la segunda, que, tras la política represiva de las cofradías iniciada por los ministros ilustrados de Carlos III, ese barniz solidario podía constituir un aval para la aprobación y supervivencia de las cofradías y hermandades. El mundo de la piedad popular se veía acorralado de día en día por las corrientes cada vez más sólidas de la política reformista y de una nueva espiritualidad ${ }^{45}$.

Buscaban ante todo eficacia y por ello su organigrama de funcionamiento era bastante simple. En los puestos directivos, salvo el caso del hermano mayor (un seglar casado), domina la presencia eclesiástica, que se cifra en los dos mencionados frailes,

43. Pormenores de esta fundación en Conde y Herrera, Cristóbal: Granada abierta a Dios en la fundación de la casa de Santa María Egipcíaca, de Madres Recogidas..., Granada, 1760.

44. Todos los datos referidos a la fundación y corta existencia de esta Vía Sacra en A.E.C.G., Libros Archivo, 38(1).

45. Cfr. EGIDo, Teófanes: «La religiosidad de los ilustrados», en La época de la Ilustración. I, vol. XXXI de Historia de España, Madrid, 1987, pp. 396-437. 
uno como celador y otro como padre de almas, y los representantes del centro donde tienen sede, es decir, la rectora y el capellán del beaterio, José Martínez de Santaella.

La relación de hermanos y hermanas incluye a consagrados, casados, viudos y solteros. Era muy importante la consignación del estado civil para delimitar las prestaciones asistenciales correspondientes a cada uno, ya que solían extenderse al ámbito familiar más inmediato. El dominio de los casados es abrumador: el 70\% presentan este estado. Se computan entre los hermanos cuarenta y cinco matrimonios, más otros dos hombres casados, sin mención del nombre de su esposa. Dejando al margen los cuatro eclesiásticos, entre las personas solas destacan, sin duda, las mujeres, que son diecinueve, incluyendo dos viudas, una soltera y otras dieciséis mujeres sin mención alguna de su estado civil, lo que llama poderosamente la atención y deja abierta la posibilidad de pensar que algunas estuvieran o hubieran estado internadas en el centro de recogimiento femenino. Entre los varones no casados ni consagrados, se cuentan dos viudos, cinco solteros y ocho sin información: en total, quince, si bien en dos casos (soltero y viudo, respectivamente, se indica que contrajeron posteriormente matrimonio, incorporando a sus esposas a la hermandad).

Estamos, por tanto, ante una realidad con variaciones. Lo normal era la composición mayoritariamente masculina de las cofradías. Aquí observamos un salto cualitativo: abundan las mujeres y no parece que los inscritos, cuyos nombres y direcciones conocemos, pertenezcan a sectores acomodados de la sociedad, como se desprende de indicios tales como los frecuentes abandonos de la nómina de afiliados (seguramente por motivos económicos) o las habituales alusiones a sus domicilios como casas de vecinos, casas-almacén o casas-taller de diversos oficios. ¿Qué hay detrás de este esbozo sociológico de la congregación? Sencillamente el interés material -también espiritual-derivado de la pertenencia a una «hermandad de socorros» ${ }^{46}$.

Pero lo llamativo es que, a la hora de escoger título y sin el pie forzado de la presión parroquial, buscaran como fórmula confraternal la de hermandad de vía sacra. Sin duda, era una modalidad devocional muy atractiva, a lo que colaboró la implicación de los frailes franciscanos. Lo dominante, empero, fue su orientación mutualista, pero siempre con la referencia o excusa de la vía sacra, nombre que todavía debía motivar en gran medida a los fieles en aquellos tiempos.

\subsection{Homogenización de modelos cofrades: el auge del mutualismo}

En primer lugar, la clásica regla o estatutos se convierten en la Vía Sacra de Recogidas en «obligaciones que voluntariamente quieren contraer los hermanos», expresión que incide mucho más en los deberes contraídos. Y, a mayor abundamiento, esas obligaciones, concretadas en ocho puntos, se completan con un «plan de caridad», con otros tantos apartados. En el ocaso del Antiguo Régimen, la mayoría de las cofradías devocionales habían abandonado las prácticas asistenciales en caso de enferme-

46. Tal y como la perfiló Rumeu de Armas, Antonio: Historia de la previsión social en España. Cofradias, Gremios, Hermandades, Montepios, Madrid, 1944 (2a. ed., Barcelona, 1981), pp. 211 y ss. 
dad -no así en caso de muerte-, de modo que «obligaciones» y «plan de caridad» se inscriben de lleno en ese modelo de hermandad de socorros mutuos ${ }^{47}$.

Un breve recorrido por su escueta reglamentación ha de comenzar por dichas obligaciones:

a. Gobierno de la corporación: se compone del padre celador, que será siempre un ministro «fervoroso y desinteresado», que preside e instruye a los asociados («sugetos a su parecer»), y un hermano mayor, el más implicado en las prácticas de culto: «lleve el cargo de ofrecer la Santa Vía Sacra y demás ejercicios y cuidar de el culto de el Señor y atraer las almas que pueda a estos santos exercicios». El padre celador o director administra a los hermanos los «auxilios espirituales» y les reprende en caso de no asistir o de relajar la frecuencia de los sacramentos. Les asisten dos hermanos, especialmente para organizar la vía sacra y para cobrar las aportaciones de los cofrades y las limosnas de los devotos. El sostén económico era fundamental, si bien debía esmaltarse con el barniz de la honestidad y la austeridad, en el sentido de distribuir convenientemente los fondos y evitar convertirse en «la censura de las jentes» a causa de «gastos vanidosos».

b. Una mención especial se hace a la comunidad del beaterio, con su rectora al frente. Se trata de una suerte de «hermandad» entre la vías sacra y las madres, «para que mutuamente se ayuden los unos a los otros con sus oraciones y ejercicios, en vida y en muerte, y por fallecimiento de alguna de las madres le ofrecerán todos los hermanos una comunión y vía sacra». Al fin y al cabo, en la iglesia del beaterio residía la corporación, y más concretamente en el altar del «Señor de la Expiración», posiblemente la imagen que hoy se venera como Cristo de los Favores en la parroquia de S. Cecilio.

c. El culto específico es el ejercicio del vía crucis, en público, «en los santuarios distinguidos para este fin», es decir las vía sacras ya existentes en la ciudad. Se realizaba los domingos y días festivos del año, así como todos los viernes, con mucha probabilidad en el interior de algún templo. Entre las vías sacras, se concreta la de S. Diego, en una ocasión conjuntamente con la congregación rosariana de la Virgen de Gracia. Se consignan cera, faroles y cruces para este ejercicio. En la última mencionada, ya en 1824, consta la presencia de «soldados realistas». La reunión de los cofrades en la iglesia el cuarto domingo de cada mes tenía por objeto la celebración de la misa. De forma más solmene se ganaba un jubileo, bien en junio o bien en septiembre (en este caso en torno a la festividad de la Exaltación de la Cruz), además de celebrar sermones de las Siete Palabras en la parroquia de La Magdalena.

d. Los integrantes de la corporación asumían tres obligaciones fundamentales: la primera era la asistencia a la vía sacra, indeclinable «a no ser por enfer-

47. Por extenso para Granada en LóPEz MuÑoz, Miguel Luis: La labor benéfico-social de las cofradias en la Granada moderna, Granada, 1994. 
medad o precisa ocupación, no olvidando que estos santos exercicios es para mejorar de vida y dar buen ejemplo a sus hermanos»; la segunda consistía en satisfacer la cantidad de un cuarto cada semana (y medio real todos los meses para el ejercicio de la vía sacra); la tercera, en fin, se cifraba en confesar y comulgar los cuartos domingos de cada mes, reunidos en la iglesia.

Estas «Obligaciones» contenían prescripciones para la hora del fallecimiento de cada hermano. Se hace en esto un especial hincapié, más incluso que en la concreción de la práctica de la vía sacra. Dos son las acciones inmediatas:

- Sabiendo que se encuentra próximo a morir, se le dice una misa en el altar del Crucificado y esa misma noche se le ofrece al santo vía crucis -probablemente en el interior del templo-, «para que el Señor le asista en aquella última hora y lo perdone»».

- Se asiste al entierro con cirios y la celebración de una misa de sufragio en el domingo o día festivo inmediato, con comunión general de los hermanos y hermanas, así como el ofrecimiento por su alma de la vía sacra de esa tarde.

Estos estatutos fueron aprobados el día 8 de julio de 1821 por los citados frailes franciscanos. También a ellos cupo la aprobación del «plan de caridad», con fecha de 5 de agosto del mismo año. Poco más de una quincena de hermanos, sin contar los dos religiosos, firman ambos documentos. El segundo testimonia el talante más propiamente mutual de la cofradía, llamada también «hospitalidad». Como fórmula mutual que implicaba un mayor desembolso económico, en principio no han de pertenecer a ella todos los cofrades. Su contenido se extracta a continuación:

a. Se administraba a través de una junta de caridad presidida por el padre celador y el padre de almas, «para socorrer a los hermanos y hermanas enfermos y asistirlos en su muerte»; se añadían los mismos religiosos en este socorro de «enfermedades peligrosas, por el trabajo que tendrán que sufrir con los hermanos en vida y en muerte».

Les asistían dos enfermeros y dos cobradores. Los enfermeros, junto al hermano mayor y los ministros, conformaban la junta de caridad, así como otros hermanos designados cuando fuese necesario. Por supuesto, era el hermano mayor quien debía valorar cada caso, y para ello mandaba a un médico a visitar al hermano enfermo en cuanto tenía noticia de ello. A partir de ahí correspondía al enfermero «visitar dicho enfermo todos los días, turnándose los dos en este trabajo por semanas, para ver el estado de su salud y el cuido que en dicha casa le tengan para su restablecimiento, y cuando estubiere inmediato a morir dar parte para que se le diga la misa para que el Señor prepare su alma a una buena muerte y se le aplique en aquella noche la santa Vía Sacra ${ }^{48}$.

48. A.E.C.G., Libros Archivo, 38(1), cláusula $2^{\mathrm{a}}$. 
b. Mención aparte merecen los cobradores, porque en esta sección de caridad la liquidez era una condición irrenunciable. De hecho, las aportaciones económicas eran importantes y se cobraban con regularidad, por lo general semanal (todos los domingos mientras hubiese un hermano enfermo):

«Deverán dar para este fondo todos los hermanos que quieran unirse a esta hospitalidad, por ahora, según las circunstancias de los tiempos, ocho reales, a más un real todos los meses para el aumento de este fondo; y cuando un hermano o hermana estubiere enfermo un cuarto diario, y si ubiere dos enfermos dos quartos; si ubiere más de tres enfermos, se les socorrerá con el dinero de el fondo que ubiere creado. Si este fondo se consumiese toda su esistencia en el socorro de los hermanos enfermos, se citará a junta general y se ará presente a los hermanos las partidas gastadas y las recibidas, y se volverá a crear otro fondo en los mismos términos que el primero, deviendo, aún cuando esté dando el quarto para el enfermo, cumplido el mes, el real asignado todos los meses para el aumento de el fondo» ${ }^{49}$.

Está claro que la «hospitalidad» dependía de los fondos, y éstos del número de enfermos. La situación podía a ser muy delicada, ya que el fondo acumulado podía gastarse en un corto tiempo. Epidemias, como la fiebre amarilla de 1804, estaban aún cercanas en el tiempo y presentes en la memoria. Quizás no todos los asociados podían afrontar con regularidad las obligaciones de pago; así se explicaría la abundancia de abandonos. El fondo, en fin, en caso de desaparecer la hospitalidad, se invertiría en el culto del Señor en la vía sacra, que era su principal obligación, hasta el punto de que quienes no contribuían con ella, no tenían derecho a exigir beneficios.

c. La tabla de prestaciones era también precisa (siempre que se estuviera al corriente del pago de las cuotas):

- Hermano y hermana viuda/soltera: por enfermedad grave 6 reales diarios, hasta su fallecimiento o hasta su curación.

- Hermano y hermana viuda/soltera: por convalecencia (máximo ocho días) 3 reales diarios.

- $\quad$ Esposa del cofrade: por enfermedad peligrosa 3 reales diarios, hasta su convalecencia.

A quienes podían sostenerse con sus propios caudales, se les daba la posibilidad de que renunciasen a la prestación a favor del culto de la vía sacra o del fondo de la hospitalidad. Curiosa invitación que evoca el origen estrictamente caritativo de la asistencia social ofrecida desde el ámbito cofrade.

d. Esa caridad se especifica en el caso (excepcional) del hermano pobre de avanzada edad que no pudiera seguir satisfaciendo la cuota. Previa presentación de un memorial, «se le socorrerá con la limosna asignada asta su fallecimiento, procurando los hermanos no eximirse, pues siempre se debe acudir a el necesitado, y más siendo hermano y que el tiempo que a podido lo a echo

49. Ibidem, cláusula $5^{\text {a }}$. 
con sus mismos hermanos; y deverá la junta de caridad, luego que algún hermano presente dicho memorial, indagar si es cierto lo que expone en su contenido para decretarlo ${ }^{50}$.

Lo más curioso es que el fondo de «hospitalidad» ofrece un saldo positivo a lo largo de aquellos años, no así las cuentas de la hermandad, cuyos gastos significaron entre 1819 y 1823 un $145 \%$ de los ingresos. ¿Fue el fondo una forma encubierta de sufragar el aparato cultual de la hermandad? Es difícil saberlo. Por otra parte, no eran raros los saldos negativos; décadas atrás la hermandad del Cristo de la Esperanza presentó un balance deficitario en todos los ejercicios económicos desde 1769 hasta $1808^{51}$

La vocación mutualista asistencial no fue exclusiva de esta cofradía de vía sacra que tuvo tan efímera existencia -su rastro desaparece en 1824-. Otra de ellas, la de Jesús de la Humildad y Stmo. Cristo de la Vía Sacra, acabó especializada en aspectos funerarios. Sus mayordomos declaraban en 1827 que el objeto de su institución era «el aumento del culto divino y el alivio de las almas del purgatorio, principalmente de los hermanos que fallecen ${ }^{52}$. Un apartado de sus constituciones se dedicaba, por tanto, a esta materia, atendiendo tanto el entierro (asistencia con estandarte y cera, colocación de ocho hachas durante los oficios, traslado del cadáver y sepultura del mismo), como los sufragios (novenario de misas rezadas, así como otras pagadas con la limosna allegada por la hermandad). Era la derivación mutual de una amplia trayectoria caritativa, que quedaba ya de manifiesto en un informe de 1769: «más de sesenta novenarios de misas que dicen cada año por los hermanos difuntos... y en una fiesta y procesión que sin superfluidad ninguna se hace anualmente y finalmente en la cera para los entierros de los hermanos, a que asisten no sólo para acompañar, sino para abrir ellos mismos la sepultura, enterrarlos y hacer todos los oficios materiales con los hermanos que mueren $\rangle^{53}$.

\section{A MODO DE CONCLUSIÓN}

Es evidente que en el ocaso del Antiguo Régimen aquellas cofradías de vía sacra ya no eran lo que fueron en origen: un revulsivo devocional dirigido a metas más altas, es decir, propiciador de actitudes de conversión personal expresadas a través de la meditación y de la mortificación, todo ello dentro de la más genuina corriente ascética de la España del Siglo de Oro.

Sin embargo, el nombre de Vía Sacra era una referencia de altura espiritual a la que no se sustraía el pueblo. Sólo así se explica la vitalidad que mantenía, la atracción que ejercía entre seglares deseosos de asociarse y el interés de la jerarquía eclesiástica

50. Ibidem, cláusula $7^{\mathrm{a}}$.

51. A.P.M., caja 48.

52. A.E.C.G., leg. 14F(A), pza. 2(10).

53. Archivo de la Parroquia del Sagrario, leg. 28. 
por trasplantar este modelo, introducido en Granada al calor de la espiritualidad franciscana, al heterogéneo mundo de la vida parroquial.

Semejante potencial devocional, en medio de parajes mitad urbanos mitad campestres, que recreaban los pasos de Jesús hasta el calvario, granjearon a estas hermandades el favor popular, que admiraba la elevación de sus prácticas, y también un plus de consideración social para sus miembros, tan característico de un mundo sacralizado y muy jerarquizado.

Por este motivo, gozaron las cofradías de vía sacra de un reconocido prestigio, tanto que fueron fomentadas por el clero como una fórmula sana, no contaminada, frente a las procesiones de Semana Santa, en las que el boato y la superfluidad -en perfecta armonía lo sagrado con lo profano- recomendaban descalificaciones cada vez más frecuentes, como se evidenciaron sin duda alguna en el ilustrado siglo XVIII. Es decir, una propuesta alternativa de profundo calado.

Desde luego, la extensión de una fórmula alentada en origen por el fervor de los regulares al amplio mundo de parroquias y ermitas ayudó a «popularizar» el modelo -se cuentan hortelanos y artesanos entre los cofrades-, pero también a desvirtuarlo. En primer lugar, porque no se vieron libres del torbellino barroco, que se constata en la creciente presencia de imágenes sagradas, enseres procesionales y actos públicos urbanos revestidos de la mayor solemnidad. En segundo lugar, porque predominó en las vías sacras el marco asociativo común al conjunto de las hermandades y cofradías, con todas sus fortalezas y debilidades.

Cabe pensar que en las primeras décadas del siglo XIX aquellas cofradías -las pocas que persistían - conservaban su renombre, pero a la vez se nos presentan plenamente incardinadas en la religiosidad «tradicional» del pueblo, despojadas ya del vigor espiritual de sus orígenes. Lo que sí es seguro es que aquéllas que se mantenían vivas derivaron hacia los modelos asistenciales propios del mutualismo, especializándose en la atención a sus afiliados, en los casos de enfermedad y de muerte. 